6. Shaker OG, Abdelhamid N. Detection of enteroviruses in pediatric patients with aseptic meningitis. Clin Neurol Neurosurg. 2015 Feb;129: 67-71. doi: 10.1016/j.clineuro.2014.12.004.

7. Yogarajah T, Ong KC, Perera D, Wong KT. Enterovirus A71 and coxsackievirus A16 show different replication kinetics in human neuronal and non-neuronal cell lines. Arch Virol. 2017 Mar;162(3):727-737. doi: 10.1007/s00705-016-3157-4.

8. Luo KW, Gao LD, Hu SX, et al. Hand, Foot, and Mouth Disease in Hunan Province, China, 2009-2014: Epidemiology and Death Risk Factors. PLoS One. 2016 Nov 29;11(11):e0167269. doi: 10.1371/ journal.pone.0167269.

DOI https://doi.org/10.30525/978-9934-26-047-6-37

\title{
THE MARGINAL NUCLEUS OF THE POSTERIOR HORNS OF THE SPINAL CORD OF EMBRYOS AND HUMAN FETUSES
}

\author{
Prykhodko S. O. \\ Assistant at the Department of Human Anatomy \\ National Pirogov Memorial Medical University, Vinnytsya \\ Vinnytsia, Ukraine \\ Shkolnikov V.S. \\ Doctor of Medical Sciences, \\ Professor at the Department of Human Anatomy \\ National Pirogov Memorial Medical University, Vinnytsya \\ Vinnytsia, Ukraine
}

The development and formation of human organs and systems will always remain a priority for scientists. Understanding the mechanisms of these processes is the basis of normal and comfortable life in the future. Also, it will provide an opportunity to control and correct organogenesis in the intrauterine period of ontogeny.

In particular, pre- and perinatal lesions of internal organs and structures of the central nervous system in children are one of the most pressing medical and social problems of modern neurology and pediatrics, due to both high mortality of young children and a significant proportion of this pathology in infant mortality or disability [1, p. 50].

There is a sufficient number of scientific reports in the available literature, which would concern studies of the central nervous system, in 
particular, the spinal cord, namely its morphology, function, or evolutionary development [2, p. 48; 3, p.87; 4, p. 303]. However, to date, data on embryogenesis and the formation of human spinal cord structures are quite outdated and are fragmented, especially concerning the posterior horns [5, p. 245].

Thus, our study aims to investigate the features of the development and formation marginal nucleus of the posterior horns of the human spinal cord in the prenatal period of ontogenesis.

The research employs anatomical, histological, morphometric, immunohistochemical, and statistical analysis methods. 131 specimens of the embryos spinal cord of embryos and human fetuses with a gestational age of 5-6 weeks up to 39-40 weeks were used as a material for this research.

The results obtained. In human embryos 5-6 weeks, the gray matter of the spinal cord just begins differentiating into anterior and posterior horns. There is no clear division of neuronal-glial complexes of the posterior horns, which is inherent in the definitive spinal cord. Relatively weak expression of synaptophysin within the posterior horns in embryos 6-7 weeks indicated the onset of synaptic connections and myelination of the fibers of the posterior cords.

In human embryos, 7-8 weeks the posterior horns begin to be outlined, but the division of the posterior horns into the apex, head, neck, and base at the same time during the spinal cord does not occur yet. However, in our opinion, it is appropriate to divide the gray matter of the posterior horns into ventral and dorsal parts. Neuronal-glial complexes of the posterior horns cannot be separated by homogeneity and cell size of all segments. At the border with the posterior cords (dorsal part of the posterior horns), there was an accumulation of relatively small cells, which in the future will form the marginal nucleus. At the same time, there is no significant difference in the size of dorsal neurons within one segment or in segments during the spinal cord (in all cases $\mathrm{p} \geq 0.05$ ) and this trend was observed up to 39-40 weeks. The beginning of the marginal nucleus relative separation was observed by us in the fetuses at a gestational age of 11-12 weeks. Differentiation of the posterior horns at the apex and head begins in the fetus 25-26 weeks and is more characteristic of the thoracic segments. At this age, there is a clear separation of the neuronal-glial complex of the marginal nucleus. It should be noted that at 39-40 weeks the definitive structure of the posterior horns of the spinal cord is absent. 
Conclusions. Clear differentiation of the gray matter of the spinal cord into anterior and posterior horns is observed at 7-8 weeks. The formation of the marginal nucleus begins at 11-12 weeks. Before birth, the process of differentiation of the posterior horns and their neuronal-glial complexes is not complete.

\title{
References:
}

1. Мавропуло, Т. К., Буяльський, О. С., \& Остромецька, В. М. (2011). Ультразвукове дослідження структур спинного мозку у недоношених новонароджених. Неонаталогія, хірургія та перинатальна медииина. 1:50-2.

2. Кочетков, А. Г., \& Эрастов, Е. Р. (2003). Морфофункциональная характеристика нейронов спинного мозга после однократных интегрирующих двигательных нагрузок. Морфология. 3;46-9.

3. Лопатина, С. В., Высоцкий, Ю. А., \& Тимофеева, Е. В. (2012). Морфометрические особенности нейронов в филогенезе. Журнал анатомии и гистопатологии. 1;87-90.

4. Greene, N. D., \& Copp, A. J. (2009). Development of the vertebrate central nervous system: formation of the neural tube. Prenat. Diagn. № 29. C. 303-311.

5. Pytel, A., Brusca, M., \& Wozniak, W. (2011). Differentiation of the nuclear groups in the posterior horn of the human embryonic spinal cord. Folia Morphol. 4;245-51.

DOI https://doi.org/10.30525/978-9934-26-047-6-38

\section{ДОСЛІДЖЕННЯ І ОЦІНКА СЕНСОМОТОРНОЇ РЕАКЦІЇ У ШКОЛЯРІВ}

\author{
Совтисік Д. Д.
}

кандидат біологічних наук, доцент,

дочент кафедри фізичної реабілітації та медико-біологічних основ

фізичного виховання

Кам'янеиь-Подільський національний університет імені Івана Огієнка м. Кам'янець-Подільський, Хмельницька область, Украйна

У психофізіологічних дослідженнях протягом багатьох років використовується метод визначення часу сенсомоторної реакції, за 